\title{
Role of Dietary Fats in the Prevention and Treatment of the Metabolic Syndrome
}

\author{
Joyce A. Nettleton ${ }^{a}$ Susan Jebb ${ }^{b}$ Ulf Risérus ${ }^{c}$ Berthold Koletzko $^{d}$ \\ Jennifer Fleming ${ }^{\mathrm{e}}$
}

a Science Voice Consulting, Denver, Colo., USA; ${ }^{b}$ Nuffield Department of Primary Care Health Sciences, University of Oxford, Oxford, UK; ' ${ }^{C}$ Department of Public Health and Caring Sciences, Clinical Nutrition and Metabolism, Uppsala University, Uppsala, Sweden; d Division of Metabolic Diseases and Nutritional Medicine, Dr. von Hauner Children's Hospital, Ludwig Maximilians University of Munich, Munich, Germany; ${ }^{e}$ Department of Nutritional Sciences, Pennsylvania State University, University Park, Pa., USA

\author{
Key Words \\ Dietary fat quality $\cdot$ Metabolic syndrome $\cdot$ Obesity $\cdot$ Weight \\ loss
}

\begin{abstract}
A symposium on the health significance of dietary fat in the prevention and treatment of the metabolic syndrome (MetS) was held at the 20th International Congress of Nutrition in Granada, Spain, on September 19, 2013. Four nutrition experts addressed the topics of dietary fat and obesity, effects of dietary fat quality in obesity and insulin resistance, influence of early nutrition on the later risk of MetS and the relative merits of high- or low-fat diets in counteracting MetS. Participants agreed that preventing weight gain and achieving weight loss in overweight and obese patients were key strategies for reducing MetS. Both low-fat and low-carbohydrate diets are associated with weight loss, but adherence to the diet is the most important factor in achieving success. Avoidance of high saturated fats contributes to lower health risks among obese, MetS and diabetic patients. Further, healthy maternal weight at conception and in pregnancy is
\end{abstract}

\begin{tabular}{ll}
\hline KARGER & $\begin{array}{l}\text { (c) 2014 S. Karger AG, Basel } \\
0250-6807 / 14 / 0642-0167 \$ 39.50 / 0\end{array}$ \\
E-Mail karger@karger.com & $\begin{array}{l}\text { This is an Open Access article licensed under the terms of the } \\
\text { www.karger.com/anm }\end{array}$ \\
$\begin{array}{l}\text { Creative Commons Attribution-NonCommercial 3.0 Un- } \\
\text { ported license (CC BY-NC) (www.karger.com/OA-license), } \\
\text { applicable to the online version of the article only. Distribu- } \\
\text { tion permitted for non-commercial purposes only. }\end{array}$
\end{tabular}

more important that weight gain during pregnancy for reducing the risk of obesity in the offspring. The effects of different polyunsaturated fatty acids on MetS and weight loss require clarification.

(c) 2014 S. Karger AG, Basel

\section{Introduction}

The metabolic syndrome (MetS) is a collection of related risk factors that increases the risk of type 2 diabetes, cardiovascular disease, stroke and other diseases. Individuals with MetS have a 5 -fold greater risk of developing type 2 diabetes and are 3 times more likely to have a heart attack or stroke compared with those without the syndrome [1]. According to the International Diabetes Federation, the worldwide prevalence of MetS is $25 \%$ and increasing rapidly [2].

The International Diabetes Federation published a worldwide definition of MetS based on central obesity defined as waist circumference with ethnicity-specific values, plus any two of the following four factors: plasma 
triglycerides $\geq 1.7 \mathrm{mmol} / \mathrm{l}(150 \mathrm{mg} / \mathrm{dl})$; high-density-lipoprotein cholesterol $<1.03 \mathrm{mmol} / \mathrm{l}(<40 \mathrm{mg} / \mathrm{dl})$ in males or $<1.29 \mathrm{mmol} / \mathrm{l}(<50 \mathrm{mg} / \mathrm{dl})$ in females; blood pressure: systolic pressure $\geq 130$ or diastolic pressure $\geq 85 \mathrm{~mm} \mathrm{Hg}$, and fasting plasma glucose $\geq 5.6 \mathrm{mmol} / \mathrm{l}(\geq 100 \mathrm{mg} / \mathrm{dl})$ [2]. It is generally agreed that insulin resistance is the principal metabolic abnormality in MetS [3,4] and is reflected in the assessment of abdominal obesity, which is easier to measure clinically.

The prevalence of MetS parallels the rising rates of obesity [5], although approximately $30 \%$ of obese individuals maintain healthy cardiometabolic profiles [6]. Similarly, not all those with insulin resistance are obese [7]. Those with abdominal obesity have the highest risk of MetS and type 2 diabetes [8]. Intervention studies have shown that weight loss and lifestyle intervention reduce the risk of progression to type 2 diabetes $[9,10]$. Improvements in diet quality beyond macronutrient distribution are significantly associated with reductions in weight, fat mass and visceral adipose tissue in MetS individuals following an energy-restricted, lifestyle intervention program for 1 year [11]. Two questions arise about the role of dietary fat in MetS: to what extent do dietary fat and fat quality contribute to weight gain or loss, and what are their effects on the development of MetS independent of weight? To address these topics, the International Expert Movement to Improve Dietary Fat Quality [12], an initiative of the International Union of Nutritional Sciences, funded by an unrestricted educational grant from Unilever $\mathrm{NV}$, hosted a symposium at the 20th International Congress of Nutrition in Granada, Spain, on September 19,2013 . This paper summarizes that symposium.

\section{Dietary Fat and Obesity}

Susan Jebb, professor of diet and population health, Oxford University, UK, traced the research on fat intake and obesity from ecological studies through controlled intervention trials and comparisons among popular weight loss programs. Her presentation addressed the question whether reducing total fat intake is crucial in weight loss or whether total energy intake matters more. Although cross-cultural studies demonstrated a linear relationship between dietary percent energy $(\% \mathrm{E})$ from fat and percent of overweight individuals in the population [13], studies among more homogeneous populations found no association [14]. Yet the efficient absorption of fat and its relative resistance to oxidation, compared with carbohydrates, suggest that high-fat diets could be par-

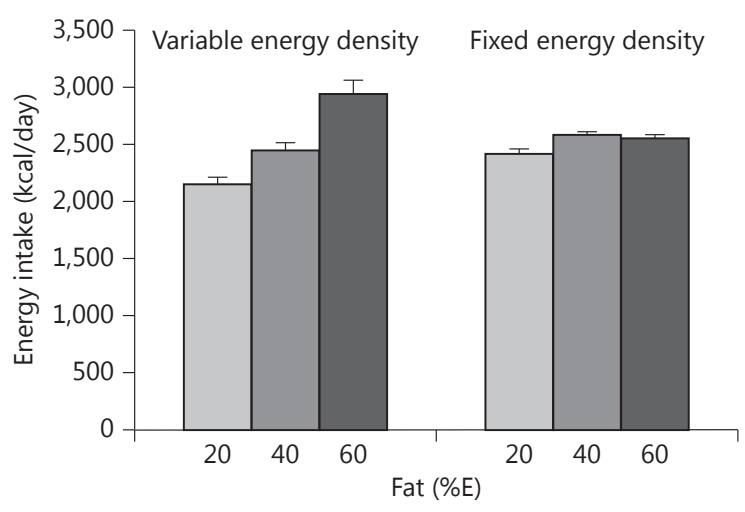

Fig. 1. High-energy diets drive the overconsumption of high-fat foods as illustrated in these studies. Ad libitum energy intake by 7 men consuming diets containing low $(20 \% \mathrm{E})$, medium $(40 \% \mathrm{E})$ or high $(60 \% \mathrm{E})$ concentrations of fat with either variable or constant energy density for 14 days [adapted from 18, 19].

ticularly liable to lead to weight gain. Experimental studies have also suggested that high-fat foods are only weakly satiating relative to other macronutrients and may contribute to passive overconsumption and excess energy intake $[15,16]$.

Detailed studies on macronutrient balance in humans during overfeeding, conducted within whole-body calorimeters, showed that while carbohydrate was readily oxidized, fat oxidation decreased as overfeeding continued, leading to fat accumulation [17]. During periods of underfeeding, fat oxidation remained high and unrelated to fat intake. Studies of men confined to a whole-body calorimeter showed that as the energy density of the diet increased (covert manipulations), ad libitum energy consumption also increased [18]. However, when the energy density of diets was held constant and the $\% \mathrm{E}$ from fat increased from 20 to $60 \%$, total energy intake remained constant (fig. 1) [19]. Other experimental studies have consistently demonstrated that energy intake increases with increasing energy density [16].

However, longer-term trials involving fat manipulations are less clear. The largest long-term randomized controlled study of low-fat diets and weight loss, the Women's Health Initiative, reported in a secondary analysis that the mean weight loss from baseline in women with a body mass index (BMI) $>30$ over 7.5 years was greatest among those who decreased their $\% \mathrm{E}$ from fat the most [20]. Mean weight loss was significantly related to $\% \mathrm{E}$ from fat, with those who consumed the highest $\% \mathrm{E}$ from fat actually gaining weight. 
Yet in a well-controlled intervention study comparing the effectiveness of three energy-restricted diets, low fat (30\%E from fat), Mediterranean (33\%E from fat) and high fat/low carbohydrate (39\%E from fat), on weight loss in moderately obese participants, Shai et al. [21] reported that after 2 years those following the low-carbohydrate or Mediterranean diets lost significantly more weight (4.7 and $4.4 \mathrm{~kg}$, respectively) than those on the low-fat diet $(2.9 \mathrm{~kg})$. After an additional 4 years without intervention, participants in the high-fat group regained $4.1 \mathrm{~kg}$, those in the low-fat group $2.7 \mathrm{~kg}$ and those following the medium-fat Mediterranean diet $1.4 \mathrm{~kg}(\mathrm{p}=0.004$ for all comparisons) [22]. Over the 6-year period, those on the Mediterranean diet had a significantly greater weight loss (3.1 $\mathrm{kg})$ compared with the low-fat $(0.6 \mathrm{~kg})$ and high-fat (1.7 $\mathrm{kg}$ ) diet groups. Differences in weight loss between the low-fat and high-fat/low-carbohydrate groups were not significant.

In a systematic review and meta-analysis of 33 randomized controlled trials and 10 cohort studies on the relation between total fat intake and body weight, Hooper et al. [23] concluded that high-quality evidence supports the association between lower fat intake and small but significant sustained reductions in body weight. Greater reductions in total fat and higher baseline fat intakes were associated with greater weight loss. The association was less clear in the 10 cohort studies where only $31 \%$ reported a significant positive association between fat content and weight gain, while in studies longer than 1 year, only half showed a significant positive association. However, all studies except 1 showed a high risk of bias.

Data from pragmatic trials of dietary interventions for weight loss show the high interindividual variability in response, suggesting the outcome may depend on factors other than the fat content of the diet. For example, a community-based open study of participants whose BMI ranged from 27 to 40 compared 4 popular weight loss programs of variable fat content with a control group who maintained their regular diet. After 6 months, all groups lost weight compared with the control group, but the mean weight loss did not differ among the programs [24]. Likewise, a similar study comparing 4 weight loss diets, including the low-fat Ornish diet and high-fat Atkins diet, reported that after 1 year, participants in each diet group lost modest amounts of weight, but the amount did not differ among diets and interindividual variability was high [25]. Increased self-reported dietary adherence was associated with greater weight loss irrespective of diet.

Jebb concluded by noting that any dietary strategy to prevent or treat obesity must address total energy intake rather than fat content per se and include behavioral strategies to maximize adherence. However, since the ultimate goal of weight loss among overweight and obese individuals is to reduce health risks, especially the burden of cardiovascular disease, it is important to consider the fatty acid composition of the diet to maximize broader health benefits.

\section{Fat Quality in Obesity and Insulin Resistance}

Ulf Risérus, associate professor of clinical nutrition and metabolism, Uppsala University, Sweden, discussed the involvement of dietary fatty acids in the development of obesity, insulin resistance and type 2 diabetes. In insulin resistance and obesity, plasma levels of free fatty acids increase because of the impaired ability of the liver, adipose tissue and skeletal muscle to take up and convert the fatty acids to glucose or store them as triglycerides. However, as adipose tissue increases, the release of free fatty acids per kilogram adipose tissue may be downregulated, so that free fatty acid concentrations in plasma may be in the normal range [26]. Insulin resistance is also associated with long-term lipid overload, as observed in the accumulation of lipids outside subcutaneous adipose tissue (ectopic fat), such as skeletal muscle, visceral and liver fat. This may result from impaired lipid deposition in adipose tissue and impaired oxidative capacity [26]. Thus, dietary effects on body weight and total body fat are expected to have less favorable metabolic effects unless abdominal and ectopic fat are decreased as well.

Dietary fat quality affects the risk of diabetes, and insulin resistance and sensitivity in healthy, obese and diabetic individuals. High serum levels of saturated fatty acids (SFA) were reported to predict the development of MetS [27], while the risk of diabetes was inversely associated with vegetable fat, polyunsaturated fatty acid (PUFA) intakes and higher serum levels of $\omega-6(n-6)$ PUFAs [28, 29 ]. However, in a large prospective cohort of women followed for 14 years, the risk of type 2 diabetes was not associated with saturated or monounsaturated fat consumption, but was significantly reduced with higher intakes of PUFA [30].

The effects of different types of dietary fatty acids on obesity and fat accumulation have not been extensively investigated. Controlled feeding studies in animals indicate that in general SFA are more fattening than similar intakes of PUFA. For example, in mice fed corn oil (high in linoleic acid, the major dietary n-6 PUFA), only $31 \%$ of the intake was deposited, whereas $56 \%$ was deposited 
in mice fed a beef tallow diet (high palmitic acid, the major dietary SFA). Some evidence suggests that diets high in SFA increase the risk of obesity [31] and weight gain [32] and reduce insulin sensitivity [33]. In a small crossover study of obese men, substitution of SFA with monounsaturated fat for 4 weeks was associated with significantly lower body weight and fat mass without a change in energy or fat intake [34]. A lifestyle study for the reduction in high blood pressure reported that a higher intake of SFA at 6 months was associated with greater weight at 18 months, whereas a lower SFA intake predicted lower body weight [32]. It has been shown in several controlled feeding studies that palmitic acid results in lower fat oxidation than diets rich in monounsaturated fatty acids [35].

A large trial among obese participants with MetS in 8 countries reported that reducing SFA intake by increasing monounsaturated fat or $\omega-3$ (n-3) PUFA or carbohydrate had no effect on insulin sensitivity when weight was stable [36]. However, a previous multicenter trial indicated a beneficial insulin-sensitizing effect of such a dietary fat modification, especially when the total fat content did not exceed 37\% E [37]. Thus, the interventional data on monounsaturated fatty acids and insulin sensitivity are inconclusive, but no large trials replacing SFA with n-6 PUFA have been conducted.

Data on the effect of increasing PUFA at the expense of SFA remain limited and inconsistent. Research in animals and humans suggest that PUFA are associated with improved weight loss in some studies, but not others [38]. In a study of individuals with type 2 diabetes, obesity without diabetes or nonobese participants, substitution of SFA with PUFA (mainly n-6 PUFA) for 5 weeks on each diet in a crossover design resulted in improved insulin sensitivity and reduced abdominal subcutaneous fat area compared with the SFA diet [39]. A comparison of conjugated linoleic acid with safflower oil (78\% linoleic acid) on weight loss in obese women with type 2 diabetes reported a lower BMI and total adipose mass after 16 weeks with conjugated linoleic acid, while higher safflower oil intake was associated with lower trunk adipose mass and fasting glucose, with no change in BMI [40]. These findings support the results reported by Summers et al. [39] and suggest a potential reduction of abdominal fat and improvement of glucose metabolism by $n-6$ PUFA in obese diabetic individuals.

Swedish investigators compared the effects of isocaloric diets rich in either PUFA (mainly n-6 PUFA) or SFA on liver fat and metabolic parameters in participants with abdominal obesity, $15 \%$ of whom had type 2 diabetes
[41]. Participants consuming foods high in $n-6$ PUFA experienced a significant reduction in liver fat measured by magnetic resonance imaging, which was inversely related to the increased serum linoleic acid levels. Compared with the PUFA diet, those on the SFA-rich diet exhibited increased liver fat. In addition, PUFA significantly reduced the visceral fat/subcutaneous fat ratio compared with the SFA diet. Despite weight-stable conditions, the PUFA-rich diet was associated with moderate improvements in blood lipids and fasting insulin, whereas the SFA diet was not. This is the first study to demonstrate a favorable effect of PUFA-rich foods on ectopic fat content in humans, independent of weight change.

In a recent study of overfeeding normal-weight individuals with foods high in SFA or n-6 PUFA for 7 weeks, those fed the SFA-rich foods had markedly increased liver fat and a 2-fold larger increase in visceral fat compared with the PUFA group (fig. 2) [42]. Those consuming the PUFA-rich foods had a nearly 3 -fold larger increase in lean tissue compared with the SFA group. The investigators concluded that in healthy humans overeating SFArich foods promotes hepatic and visceral fat storage, whereas excess energy from n-6 PUFA was associated with increased lean tissue. These findings are consistent with the observations reported in individuals with abdominal obesity [41].

n-3 PUFA may have different effects from linoleic acid. Most research has focused on the long-chain (LC) n-3 PUFA, primarily eicosapentaenoic acid and docosahexaenoic acid found mainly in fish and shellfish. Rodent studies have shown that fish oil or n-3 LC-PUFA can reduce diet-induced obesity [43], have a hypolipidemic effect on the liver [44], increase fatty acid oxidation in adipose tissue [45], inhibit fat cell proliferation [46], limit fat cell hypertrophy and hyperplasia [47], and stimulate mitochondrial biogenesis and $\beta$-oxidation in white adipose tissue [48]. Thus, an extensive literature of animal studies supports the anti-obesity effects of n-3 LC-PUFA.

Studies on the effects of $n-3$ PUFA in humans are scarce [49]. Data from epidemiological studies are inconsistent, but several large studies reported an inverse association between fish consumption or $\mathrm{n}-3$ LC-PUFA intakes and BMI or abdominal obesity [50, 51]. In severely obese women following a very-low-calorie diet, the addition of $2.8 \mathrm{~g} /$ day of n-3 LC-PUFA was associated with a significantly greater loss in BMI and hip circumference compared with unsupplemented participants [52]. However, the addition of supplemental n-3 LC-PUFA to a 24week diet and exercise program provided no additional benefit for weight loss in overweight and obese individu- 
Fig. 2. Relative changes in liver fat (\%), visceral adipose tissue (ratio of visceral adipose tissue/total adipose tissue - visceral adipose tissue), total body fat and lean tissue (liters) by MRI during 7 weeks of overeating SFA or PUFA. Relative changes are calculated for each individual as a change during the intervention/baseline measurement. Boxes represent medians and interquartile ranges (IQR), whiskers represent the most extreme value besides outliers, circles represent outliers ( $>1.5$ IQRs outside IQR). p values represent changes from week 7 to week 0 (between-group t test or Wilcoxon test) [reproduced with permission from 42].
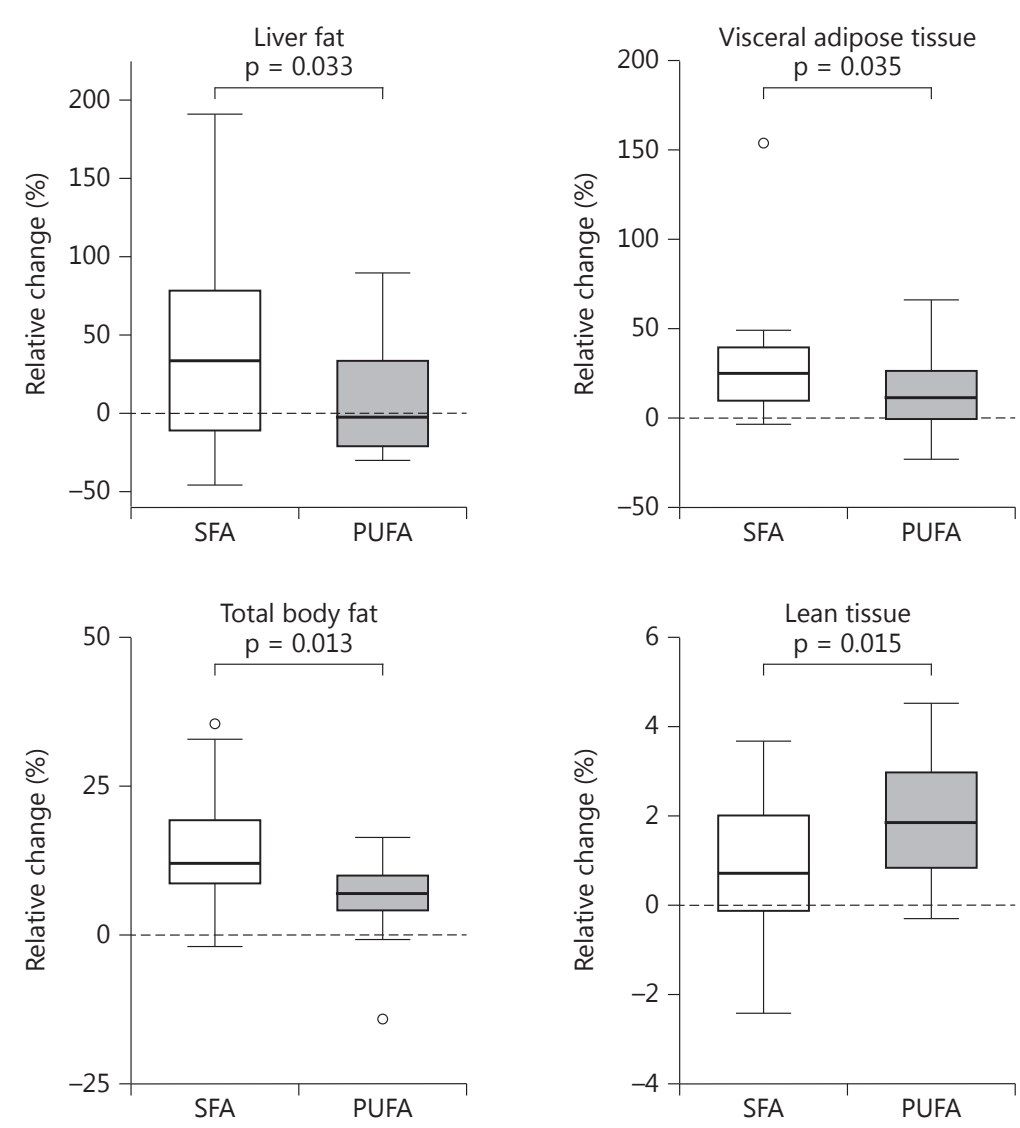

als [53]. In contrast, the addition of a daily fish meal to a weight loss diet was more effective than the weight loss diet alone in achieving weight loss over 16 weeks [54]. Fish consumption was not associated with 5- to 10-year weight gain in a large prospective cohort study [55]. In a controlled 16-week study in overweight and moderately obese healthy adults, increasing the dietary content of $\mathrm{n}-3$ PUFA to $3.6 \% \mathrm{E}$ mainly from fish oil had no effect on body weight or fat mass [56]. A recent review reached a similar conclusion [57]. Thus, fish or $n-3$ PUFA intakes may have little effect on body weight or weight gain.

Suggestive data, although limited, indicate that dietary fat quality may affect the development of adipose tissue accumulation and distribution. The effect of dietary fat quality in modulating ectopic fat is of clinical interest, as liver fat is closely linked to type 2 diabetes. As knowledge grows, it may be possible to compose optimal diets that minimize abdominal and ectopic fat accumulation, thereby helping to prevent obesity and its related metabolic disorders.

Effect of Dietary Fats on MetS

\section{Early Lipid Nutrition and Later Risk of MetS}

Recognizing the rising tide of obesity and type 2 diabetes, Prof. Berthold Koletzko, University of Munich Medical Center, Munich, Germany, emphasized the importance of early intervention to prevent obesity. Halting the epidemic of overweight and obesity is urgent because of the many adverse health conditions linked to obesity, the extension of the disorder into early childhood, and the growing prevalence of obesity in lowerincome countries [58]. In the US, more than $35 \%$ of adults and $17 \%$ of children and adolescents were obese in 2009-2010 [59].

Efforts to better understand the etiology of obesity beyond overeating and physical inactivity call attention to events in fetal and early life. Studies on early programming during fetal and postnatal life suggest interventions with the potential to deter obesity [60]. So compelling is the problem and the importance of early nutrition that a worldwide project to investigate the long-term effects of 


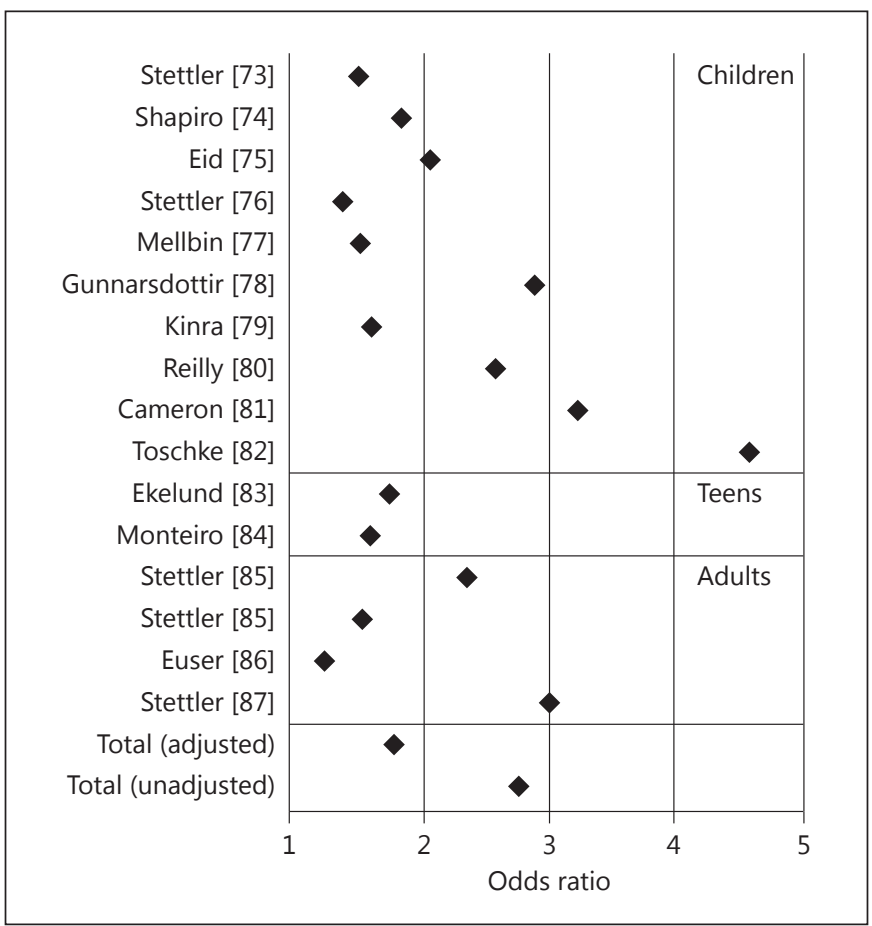

Fig. 3. Risk (odds ratios) of obesity in childhood, adolescence and adulthood with rapid weight gain in infancy or the first 2 years of life based on data from 16 studies [89] and adapted from Adair [123]. The adjusted risk of obesity across all ages exceeded 1 . Obesity was defined as BMI $>95$ th percentile and rapid weight gain as an increase in weight $\mathrm{z}$-score exceeding $0.67 \mathrm{SD}$.

early nutrition on later health has been initiated, which was funded by the European Union [61].

Three hypotheses for early developmental programming for obesity have been proposed: (1) 'fetal overnutrition' suggests that excess exposure to fuels, as occurs in gestational diabetes, causes changes that lead to obesity [62]; (2) accelerated postnatal weight gain proposes an association between rapid weight gain in infancy and an increased risk of later obesity [63], and (3) mismatch between fetal undernutrition and postnatal overnutrition suggests that experiencing suboptimal fetal nutrition and an obesogenic childhood environment predisposes to obesity. A well-known example of the latter is the survivors of the Dutch famine in the winter of 1944-1945, many of whom were born small for gestational age and later experienced increased incidence of obesity, diabetes and other chronic diseases [64].

Excessive perinatal fuel supply of glucose or fat promotes higher insulin and greater fetal fat deposition during the last trimester [65]. Women with gestational diabetes or mild glucose intolerance and obesity have at least
Table 1. Odds ratios [OR $( \pm 95 \% \mathrm{CI})]$ for child overweight or obesity according to maternal and infant predictive factors [adapted from 95]

\begin{tabular}{lll} 
Predictive factor & $\begin{array}{l}\text { Adjusted OR }(95 \% \mathrm{CI}) \\
\text { for child overweight or } \\
\text { obesity at age 7 years }\end{array}$ & $\begin{array}{l}\text { Adjusted OR }(95 \% \mathrm{CI}) \\
\text { for second-generation } \\
\text { child overweight or } \\
\text { obesity at age 4-9 yea }\end{array}$ \\
\hline $\begin{array}{l}\text { Maternal over- } \\
\quad \text { weight }\end{array}$ & $1.45(1.19-1.75)$ & $1.69(1.00-2.85)$ \\
$\begin{array}{l}\text { Maternal obesity } \\
\text { Birth weight }\end{array}$ & $2.29(1.76-2.97)$ & $3.20(1.85-5.54)$ \\
& $1.49(1.23-1.80)$ & $1.60(1.17-2.20)$
\end{tabular}

a 3-fold greater risk of having an infant above the 90th percentile in body weight and percent body fat $[66,67]$. Substantial data indicate that maternal obesity predisposes the infant to overweight, obesity and MetS [68-70].

Rapid weight gain in infancy has consistently been associated with a significantly higher risk of overweight or obesity in preschool and young children [71, 72] (fig. 3), as recently reviewed [88, 89]. More rapid childhood growth is also associated with a higher risk of obesity in adult life [90], insulin resistance [91], components of MetS [92] and a more atherogenic lipid profile in adolescence [93]. A high-protein infant formula also contributes to greater BMI and insulin-like growth factor- 1 in infants at 6 months through 2 years of age compared with breastfed infants or those fed lower protein formula [94].

There appears to be a transgenerational effect of obesity, with the strength of the association between parental and childhood obesity increasing between generations [95], as shown in table 1. Few studies have examined this question, but a study on the birth information of mothers and their offspring from the Swedish Medical Birth Register reported that mothers born large for gestational age had increased risks of overweight and obesity and were at an increased risk of having a large-for-gestational-age infant as their BMI increased [96]. Interestingly, mothers born small for gestational age had the highest risk - 13 times greater - of having large-for-gestational-age offspring. Similarly, US data reported that the strongest persistence of BMI across generations occurred among those with higher BMI levels [97].

The final question discussed by Koletzko was whether the relative proportions of dietary $n-6$ and n-3 PUFA contribute to obesity and MetS risk. In many western countries, the increased consumption of n-6 PUFA, mainly from linoleic-acid-rich vegetable oils, and re- 
duced intakes of n-3 PUFA parallel the sharp increase in the prevalence of obesity and type 2 diabetes [98-100]. Although the number of adipocytes is established in childhood [101], the greatest proliferation and differentiation of adipocyte precursor cells occurs during the 1st year of life and at prepuberty [102]. In animals, diets high in n-6 PUFA increase the differentiation and proliferation of preadipocytes, which increases the number of adipocytes and the accumulation of fat $[103,104]$. Animals fed $35 \%$ fat diets containing either 1 or $8 \% \mathrm{E}$ from linoleic acid or $8 \%$ linoleic acid plus $1 \%$ n-3 LC-PUFA exhibited increased obesity on the $8 \%$ linoleic acid diet, but had equivalent fat tissue when fed either level of linoleic acid supplemented with n-3 LC-PUFA [105]. Similar findings were reported in mice fed diets rich in linoleic acid or linoleic acid plus $\alpha$-linolenic acid, where fat mass and adipocyte size at 8 weeks were higher in the linoleic acid-fed animals compared with those fed both n-6 and n-3 PUFA [106]. Little robust animal data exist on the effects of increased perinatal PUFA exposure on body fat mass in the offspring.

In humans, observational studies suggest that high maternal plasma n-6 PUFA at 34 weeks of gestation predicted offspring fat mass at 4 and 6 years of age [107]. A study of maternal PUFA intake and status during pregnancy and child adiposity at age 3 years reported that a higher ratio of n-6:n-3 PUFA in the maternal diet, plasma and cord blood was associated with higher child adiposity [108]. In the same study, higher maternal docosahexaenoic and eicosapentaenoic acid intakes were associated with a lower skinfold thickness measures at age 3 . Fish oil supplementation in pregnancy was unrelated to adolescent obesity at 19 years of age [109]. A recent intervention study examined the reduction in the maternal intake of n-6:n-3 LC-PUFA during pregnancy and the first 4 months of lactation [110]. Participants were counseled to reduce their intake of arachidonic acid and consume a daily supplement providing $1,020 \mathrm{mg}$ docosahexaenoic acid, $180 \mathrm{mg}$ eicosapentaenoic acid and $9 \mathrm{mg}$ of vitamin E. The control group was counseled to eat a healthy diet. Up to 12 months of age, there were no statistically significant differences in the fat mass or skinfold thickness measurements in the offspring of the intervention and control groups.

Overall, few randomized controlled trials have investigated different intakes of n-6 and n-3 PUFA in pregnancy and subsequent offspring obesity. Two reviews of human studies on child adiposity and maternal LCPUFA intake reported inconsistent findings on PUFA intakes and offspring BMI or obesity $[111,112]$. Thus, the quantity and quality of available data in humans permit no conclusions about LC-PUFA and childhood obesity.

Koletzko concluded that pre- and postnatal overfeeding increases the risk for obesity and associated disorders and that it is biologically plausible that diets high in n-6 PUFA or high in n-6:n-3 PUFA could have potential adverse effects on pre- and postnatal obesity. He noted that n-3 LC-PUFA may have potential benefits on insulin sensitivity and associated outcomes in overweight children and emphasized that high SFA diets should be avoided, but at this time evidence for a causal relationship is not available. Currently, there is no basis to change current recommendations on dietary fat quality in pregnancy, lactation and infancy.

\section{Do High- or Low-Fat Diets Counteract MetS?}

Weight loss is the first line of defense in MetS, affirmed Jennifer Fleming, Pennsylvania State University, University Park, Pa., USA. Weight reduction strategies have focused primarily on the effectiveness of reducedcarbohydrate $(<50 \%$ total $\mathrm{E})$ versus low-fat $(<30 \% \mathrm{E}) \mathrm{di}-$ ets. Although both diets are associated with weight loss [113], intervention studies with reduced dietary fat have not consistently achieved positive long-term results on body weight or MetS criteria despite short-term weight loss. In contrast, reduced-carbohydrate diets have demonstrated improved blood lipid profiles, reduced blood pressure, plasma glucose and visceral adiposity, and have been associated with long-term weight loss (i.e. 2 years) [21]. A recent review by Schwingshackl and Hoffmann [114] supports these findings. However, Sacks et al. [115] reported no differences in weight loss after 2 years between those following low-fat $(20 \% \mathrm{E})$, high-carbohydrate $(55-65 \% \mathrm{E})$ versus high-fat $(40 \% \mathrm{E})$, lowercarbohydrate $(35-45 \% \mathrm{E})$ diets with varying protein content. However, the macronutrient targets of the diets were not met. Notably, the greatest weight loss occurred among those with the highest dietary compliance. This observation was reinforced by results from the A to $\mathrm{Z}$ weight loss study [116]. Collectively, research shows that beyond focusing on the macronutrient profile, it is important to identify a dietary pattern that can be followed long-term.

Emerging evidence suggests that certain dietary patterns may be more effective for weight loss in some overweight or obese groups depending on their metabolic status, particularly their insulin sensitivity. Risk factors for type 2 diabetes and cardiovascular disease vary substan- 
tially among obese individuals, with insulin resistance characterizing those with the greatest risk [117].

A study comparing two reduced energy diets, either high in carbohydrates $(60 \% \mathrm{E})$ and low in fat $(20 \% \mathrm{E})$ or low in carbohydrates $(40 \% \mathrm{E})$ and high in fat $(40 \% \mathrm{E})$, in obese women who were either insulin sensitive or insulin resistant found that the insulin-sensitive women consuming the high-carbohydrate diet lost significantly more weight than insulin-sensitive women consuming the low-carbohydrate, high-fat diet (13.5 vs. $6.8 \%$ of initial body weight, respectively). In contrast, insulin-resistant women lost significantly more weight on the lowcarbohydrate diet compared with the insulin-resistant women consuming the high-carbohydrate diet (13.4 vs. $8.5 \%$ of initial body weight, respectively) [118]. The investigators concluded that the state of insulin sensitivity determined the effectiveness of the macronutrient distribution in the weight loss diets consumed by these obese women.

In an 18-month study comparing a low-glycemic-load diet (40\% carbohydrate and 35\% fat) with a low-fat diet (55\% carbohydrate and $20 \%$ fat) in obese young adults, participants with an insulin concentration above the median 30 min after an oral glucose dose consuming the low glycemic load diet experienced greater weight loss $(-5.8$ vs. $-1.2 \mathrm{~kg} ; \mathrm{p}=0.004)$ and decreased percent body fat ( -2.6 vs. $-0.9 \% ; \mathrm{p}=0.03)$ than those consuming the lowfat diet [119]. The authors suggested that reducing the glycemic load might be especially important for achieving weight loss in individuals with high insulin secretion. Consistent with these findings was the observation that adherence to either a low-fat $(\leq 10 \% \mathrm{E})$ or low-carbohydrate ( $\leq 50 \mathrm{~g} /$ day) diet among obese women was related to the insulin resistance status only for those on the lowfat diet [105]. Insulin-resistant participants were less likely to adhere to and lose weight on a low-fat diet compared to insulin-sensitive participants. Further, insulin-resistant women who consumed the low-carbohydrate diet experienced a significant reduction in their fasting insulin level compared with participants consuming the lowfat diet ( -5.8 vs. $-0.2 \mu \mathrm{IU} / \mathrm{ml}, \mathrm{p}<0.0001)$ or with insulinsensitive women on the same diet $(-5.8$ vs. $0.1 \mu \mathrm{IU} / \mathrm{ml}$, $\mathrm{p}<0.001)$ [120].

When designing low-carbohydrate diets, the question arises whether protein or unsaturated fat should replace the carbohydrate. In a study comparing carbohydrate replacement with protein or monounsaturated fat in the diets of overweight and obese volunteers with elevated fasting insulin levels $(>12 \mathrm{mU} / \mathrm{l})$, investigators reported that weight loss (approx. $10 \mathrm{~kg}$ ), improvements in insulin resistance and changes in cardiovascular risk factors did not differ between the groups after 12 weeks of energy restriction [121]. Fleming cautioned that the long-term effects of high-protein diets have not been extensively investigated, may be high in SFA and/or low in nutrient density, may be expensive or impractical, and are associated with declining adherence over time. Whether the replacement fat should be predominately monounsaturated or PUFA is unclear, as both types of fat are associated with improved lipid profile, increased insulin sensitivity, and lower blood pressure and abdominal fat when compared with dietary carbohydrate.

Fleming shared findings from a meta-analysis of 50 studies of the Mediterranean diet in patients with MetS, which reported significant associations between the diet and reduced waist circumference, increased HDL-cholesterol and lower triglyceride levels, lower systolic and diastolic blood pressures, and reduced glucose levels and insulin resistance [122]. These studies suggest that successful management of MetS is dependent on dietary patterns that have a moderate macronutrient composition and are nutrient dense.

The symposium participants agreed that preventing weight gain and tackling weight loss are key strategies for reducing MetS. Both low-fat and low-carbohydrate diets can lead to weight loss, but adherence to the dietary strategy trumps the macronutrient distribution. Avoiding high SFA diets contributes to a reduction in health risks for obese, MetS and diabetic patients. Healthy maternal weight at conception and in pregnancy is more important than weight gain during pregnancy in affecting the risk of obesity in the offspring. The effects of different PUFA distributions on MetS and weight loss await clarification.

\section{Acknowledgments}

Selected material from this paper was originally presented at the 20th International Congress of Nutrition in Granada, Spain, on September 19, 2013. Unilever, The Netherlands, provided financial assistance for this publication.

\section{Disclosure Statement}

The authors declare no conflicts of interest. 


\section{References}

1 International Diabetes Federation: IDF, Diabetes Atlas, ed 6. Brussels, International Diabetes Federation, 2013.

2 International Diabetes Federation: The IDF Consensus Worldwide Definition of the Metabolic Syndrome. Brussels, International Diabetes Federation, 2006.

-3 DeFronzo RA, Ferrannini E: Insulin resistance. A multifaceted syndrome responsible for NIDDM, obesity, hypertension, dyslipidemia, and atherosclerotic cardiovascular disease. Diabetes Care 1991;14:173-194.

-4 Bremer AA, Mietus-Snyder M, Lustig RH: Toward a unifying hypothesis of metabolic syndrome. Pediatrics 2012;129:557-570.

-5 Ervin RB: Prevalence of metabolic syndrome among adults 20 years of age and over, by sex, age, race and ethnicity, and body mass index: United States, 2003-2006. Natl Health Stat Report 2009;13:1-7.

$\checkmark 6$ Wildman RP: Healthy obesity. Curr Opin 19 Clin Nutr Metab Care 2009;12:438-443.

-7 Petersen KF, Dufour S, Savage DB, Bilz S, Solomon G, Yonemitsu S, Cline GW, Befroy D, Zemany L, Kahn BB, Papademetris X, Rothman DL, Shulman GI: The role of skeletal muscle insulin resistance in the pathogenesis of the metabolic syndrome. Proc Natl Acad Sci USA 2007;104:12587-12594.

8 Despres JP: Is visceral obesity the cause of the metabolic syndrome? Ann Med 2006;38:5263.

9 Penn L, White M, Lindstrom J, den Boer AT, Blaak E, Eriksson JG, Feskens E, Ilanne-Parikka P, Keinanen-Kiukaanniemi SM, Walker M, Mathers JC, Uusitupa M, Tuomilehto J: Importance of weight loss maintenance and risk prediction in the prevention of type $2 \mathrm{di}$ abetes: analysis of European Diabetes Prevention Study RCT. PLoS One 2013;8:e57143.

10 Diabetes Prevention Program Research G, Knowler WC, Fowler SE, Hamman RF, Christophi CA, Hoffman HJ, Brenneman AT, Brown-Friday JO, Goldberg R, Venditti E, Nathan DM: 10-year follow-up of diabetes incidence and weight loss in the Diabetes Prevention Program Outcomes Study. Lancet 2009;374:1677-1686.

11 Nazare JA, Smith J, Borel AL, Almeras N, Tremblay A, Bergeron J, Poirier P, Despres JP: Changes in both global diet quality and physical activity level synergistically reduce visceral adiposity in men with features of metabolic syndrome. J Nutr 2013;143:1074-1083.

12 International Expert Movement: International Expert Movement to Improve Dietary Fat Quality. Vlaardingen, Unilever/International Union of Nutritional Science, 2014.

$\checkmark 13$ Bray GA, Popkin BM: Dietary fat intake does affect obesity! Am J Clin Nutr 1998;68:11571173.

14 Lissner L, Heitmann BL: Dietary fat and obesity: evidence from epidemiology. Eur J Clin Nutr 1995;49:79-90.
15 Blundell JE, Burley VJ, Cotton JR, Lawton CL: Dietary fat and the control of energy intake: evaluating the effects of fat on meal size and postmeal satiety. Am J Clin Nutr 1993;57: 772S-777S; discussion 777S-778S.

16 Prentice AM: Manipulation of dietary fat and energy density and subsequent effects on substrate flux and food intake. Am J Clin Nutr 1998;67:535S-541S.

17 Jebb SA, Prentice AM, Goldberg GR, Murgatroyd PR, Black AE, Coward WA: Changes in macronutrient balance during over- and underfeeding assessed by 12-d continuous whole-body calorimetry. Am J Clin Nutr 1996;64:259-266.

18 Stubbs RJ, Harbron CG, Murgatroyd PR, Prentice AM: Covert manipulation of dietary fat and energy density: effect on substrate flux and food intake in men eating ad libitum. Am J Clin Nutr 1995;62:316-329.

Stubbs RJ, Harbron CG, Prentice AM: Covert manipulation of the dietary fat to carbohydrate ratio of isoenergetically dense diets: effect on food intake in feeding men ad libitum. Int J Obes Relat Metab Disord 1996;20:651660.

20 Howard BV, Manson JE, Stefanick ML, Beresford SA, Frank G, Jones B, Rodabough RJ, Snetselaar L, Thomson C, Tinker L, Vitolins M, Prentice R: Low-fat dietary pattern and weight change over 7 years: the Women's Health Initiative Dietary Modification Trial. JAMA 2006;295:39-49.

21 Shai I, Schwarzfuchs D, Henkin Y, Shahar DR, Witkow S, Greenberg I, Golan R, Fraser D, Bolotin A, Vardi H, Tangi-Rozental O, Zuk-Ramot R, Sarusi B, Brickner D, Schwartz Z, Sheiner E, Marko R, Katorza E, Thiery J, Fiedler GM, Bluher M, Stumvoll M, Stampfer MJ: Weight loss with a low-carbohydrate, Mediterranean, or low-fat diet. N Engl J Med 2008;359:229-241.

22 Schwarzfuchs D, Golan R, Shai I: Four-year follow-up after two-year dietary interventions. N Engl J Med 2012;367:1373-1374.

23 Hooper L, Abdelhamid A, Moore HJ, Douthwaite W, Skeaff CM, Summerbell CD: Effect of reducing total fat intake on body weight: systematic review and meta-analysis of randomised controlled trials and cohort studies. BMJ 2012;345:e7666.

24 Truby H, Baic S, deLooy A, Fox KR, Livingstone MB, Logan CM, Macdonald IA, Morgan LM, Taylor MA, Millward DJ: Randomised controlled trial of four commercial weight loss programmes in the UK: initial findings from the BBC 'diet trials'. BMJ 2006; 332:1309-1314.

25 Dansinger ML, Gleason JA, Griffith JL, Selker HP, Schaefer EJ: Comparison of the Atkins, Ornish, Weight Watchers, and Zone diets for weight loss and heart disease risk reduction: a randomized trial. JAMA 2005;293:43-53.
26 Karpe F, Dickmann JR, Frayn KN: Fatty acids, obesity, and insulin resistance: time for a reevaluation. Diabetes 2011;60:2441-2449.

27 Warensjo E, Riserus U, Vessby B: Fatty acid composition of serum lipids predicts the development of the metabolic syndrome in men. Diabetologia 2005;48:1999-2005.

-28 Meyer KA, Kushi LH, Jacobs DR Jr, Folsom AR: Dietary fat and incidence of type 2 diabetes in older Iowa women. Diabetes Care 2001; 24:1528-1535.

29 Vanhala M, Saltevo J, Soininen P, Kautiainen H, Kangas AJ, Ala-Korpela M, Mantyselka P: Serum omega-6 polyunsaturated fatty acids and the metabolic syndrome: a longitudinal population-based cohort study. Am J Epidemiol 2012;176:253-260.

30 Salmeron J, Hu FB, Manson JE, Stampfer MJ, Colditz GA, Rimm EB, Willett WC: Dietary fat intake and risk of type 2 diabetes in women. Am J Clin Nutr 2001;73:1019-1026.

31 Phillips CM, Kesse-Guyot E, McManus R, Hercberg S, Lairon D, Planells R, Roche HM: High dietary saturated fat intake accentuates obesity risk associated with the fat mass and obesity-associated gene in adults. J Nutr 2012; 142:824-831.

32 Lin PH, Wang Y, Grambow SC, Goggins W, Almirall D: Dietary saturated fat intake is negatively associated with weight maintenance among the PREMIER participants. Obesity (Silver Spring) 2012;20:571-575.

-33 Vessby B: Dietary fat and insulin action in humans. Br J Nutr 2000;83(suppl 1):S91-S96.

-34 Piers LS, Walker KZ, Stoney RM, Soares MJ, O'Dea K: Substitution of saturated with monounsaturated fat in a 4 -week diet affects body weight and composition of overweight and obese men. Br J Nutr 2003;90:717-727.

35 Kien CL, Bunn JY, Ugrasbul F: Increasing dietary palmitic acid decreases fat oxidation and daily energy expenditure. Am J Clin Nutr 2005;82:320-326.

- 36 Tierney AC, McMonagle J, Shaw DI, Gulseth HL, Helal O, Saris WH, Paniagua JA, Golabek-Leszczynska I, Defoort C, Williams CM, Karsltrom B, Vessby B, Dembinska-Kiec A Lopez-Miranda J, Blaak EE, Drevon CA, Gibney MJ, Lovegrove JA, Roche HM: Effects of dietary fat modification on insulin sensitivity and on other risk factors of the metabolic syndrome - LIPGENE: a European randomized dietary intervention study. Int J Obes (Lond) 2011;35:800-809.

37 Vessby B, Uusitupa M, Hermansen K, Riccardi G, Rivellese AA, Tapsell LC, Nalsen C, Berglund L, Louheranta A, Rasmussen BM, Calvert GD, Maffetone A, Pedersen E, Gustafsson IB, Storlien LH: Substituting dietary saturated for monounsaturated fat impairs insulin sensitivity in healthy men and women: the KANWU Study. Diabetologia 2001;44: 312-319. 
38 Tan SY, Batterham M, Tapsell L: Increased intake of dietary polyunsaturated fat does not promote whole body or preferential abdominal fat mass loss in overweight adults. Obes Facts 2011;4:352-357.

- 39 Summers LK, Fielding BA, Bradshaw HA, Ilic V, Beysen C, Clark ML, Moore NR, Frayn KN: Substituting dietary saturated fat with polyunsaturated fat changes abdominal fat distribution and improves insulin sensitivity. Diabetologia 2002;45:369-377.

-40 Norris LE, Collene AL, Asp ML, Hsu JC, Liu LF, Richardson JR, Li D, Bell D, Osei K, Jackson RD, Belury MA: Comparison of dietary conjugated linoleic acid with safflower oil on body composition in obese postmenopausal women with type 2 diabetes mellitus. Am J Clin Nutr 2009;90:468-476.

-41 Bjermo H, Iggman D, Kullberg J, Dahlman I, Johansson L, Persson L, Berglund J, Pulkki K, Basu S, Uusitupa M, Rudling M, Arner P, Cederholm T, Ahlstrom H, Riserus U: Effects of n-6 PUFAs compared with SFAs on liver fat, lipoproteins, and inflammation in abdominal obesity: a randomized controlled trial. Am J Clin Nutr 2012;95:1003-1012.

-42 Rosqvist F, Iggman D, Kullberg J, Jonathan Cedernaes J, Johansson HE, Larsson A, Johansson L, Ahlstrom H, Arner P, Dahlman I, Riserus U: Overfeeding polyunsaturated and saturated fat causes distinct effects on liver and visceral fat accumulation in humans. Diabetes 2014;63:2356-2368.

43 Buckley JD, Howe PR: Long-chain omega-3 polyunsaturated fatty acids may be beneficial for reducing obesity - a review. Nutrients 2010;2:1212-1230.

-44 Lombardo YB, Hein G, Chicco A: Metabolic syndrome: effects of $n-3$ PUFAs on a model of dyslipidemia, insulin resistance and adiposity. Lipids 2007;42:427-437.

45 Flachs P, Rossmeisl M, Kuda O, Kopecky J: Stimulation of mitochondrial oxidative capacity in white fat independent of UCP1: a key to lean phenotype. Biochim Biophys Acta 2013;1831:986-1003.

46 Hensler M, Bardova K, Jilkova ZM, Wahli W, Meztger D, Chambon P, Kopecky J, Flachs P: The inhibition of fat cell proliferation by $n-3$ fatty acids in dietary obese mice. Lipids Health Dis 2011;10:128.

-47 Ruzickova J, Rossmeisl M, Prazak T, Flachs P, Sponarova J, Veck M, Tvrzicka E, Bryhn M, Kopecky J: Omega-3 PUFA of marine origin limit diet-induced obesity in mice by reducing cellularity of adipose tissue. Lipids 2004; 39:1177-1185.

-48 Flachs P, Horakova O, Brauner P, Rossmeisl M, Pecina P, Franssen-van Hal N, Ruzickova J, Sponarova J, Drahota Z, Vlcek C, Keijer J, Houstek J, Kopecky J: Polyunsaturated fatty acids of marine origin upregulate mitochondrial biogenesis and induce beta-oxidation in white fat. Diabetologia 2005;48:2365-2375.
49 Mori T, Kondo H, Hase T, Tokimitsu I, Murase T: Dietary fish oil upregulates intestinal lipid metabolism and reduces body weight gain in C57BL/6J mice. J Nutr 2007;137: 2629-2634.

$50 \mathrm{He}$ K, Rimm EB, Merchant A, Rosner BA, Stampfer MJ, Willett WC, Ascherio A: Fish consumption and risk of stroke in men. JAMA 2002;288:3130-3136.

51 Garaulet M, Perez-Llamas F, Perez-Ayala M, Martinez P, de Medina FS, Tebar FJ, Zamora S: Site-specific differences in the fatty acid composition of abdominal adipose tissue in an obese population from a Mediterranean area: relation with dietary fatty acids, plasma lipid profile, serum insulin, and central obesity. Am J Clin Nutr 2001;74:585-591.

52 Kunesova M, Braunerova R, Hlavaty $\mathrm{P}$, Tvrzicka E, Stankova B, Skrha J, Hilgertova J, Hill M, Kopecky J, Wagenknecht M, Hainer V, Matoulek M, Parizkova J, Zak A, Svacina S: The influence of $n-3$ polyunsaturated fatty acids and very low calorie diet during a shortterm weight reducing regimen on weight loss and serum fatty acid composition in severely obese women. Physiol Res 2006;55:63-72.

53 DeFina LF, Marcoux LG, Devers SM, Cleaver JP, Willis BL: Effects of omega-3 supplementation in combination with diet and exercise on weight loss and body composition. Am J Clin Nutr 2011;93:455-462.

54 Mori TA, Bao DQ, Burke V, Puddey IB, Watts GF, Beilin LJ: Dietary fish as a major component of a weight-loss diet: effect on serum lipids, glucose, and insulin metabolism in overweight hypertensive subjects. Am J Clin Nutr 1999; 70:817-825.

55 Jakobsen MU, Dethlefsen C, Due KM, May AM, Romaguera D, Vergnaud AC, Norat T, Sorensen TI, Halkjaer J, Tjonneland A, Boutron-Ruault MC, Clavel-Chapelon F, Fagherazzi G, Teucher B, Kuhn T, Bergmann MM, Boeing H, Naska A, Orfanos P, Trichopoulou A, Palli D, Santucci De Magistris M, Sieri S, Bueno-de-Mesquita HB, van der A DL, Engeset D, Hjartaker A, Rodriguez L, Agudo A, Molina-Montes E, Huerta JM, Barricarte A, Amiano P, Manjer J, Wirfalt E, Hallmans G, Johansson I, Khaw KT, Wareham NJ, Key TJ, Chajes V, Slimani N, Riboli E, Peeters PH, Overvad K: Fish consumption and subsequent change in body weight in European women and men. Br J Nutr 2013;109:353-362.

56 Kratz M, Callahan HS, Yang PY, Matthys CC, Weigle DS: Dietary n-3-polyunsaturated fatty acids and energy balance in overweight or moderately obese men and women: a randomized controlled trial. Nutr Metab (Lond) 2009;6:24.

57 Martinez-Victoria E, Yago MD: Omega 3 polyunsaturated fatty acids and body weight. Br J Nutr 2012;107(suppl 2):S107-S116.

58 Swinburn BA, Sacks G, Hall KD, McPherson K, Finegood DT, Moodie ML, Gortmaker SL: The global obesity pandemic: shaped by global drivers and local environments. Lancet 2011;378:804-814.
59 Ogden CL, Carroll MD, Kit BK, Flegal KM: Prevalence of obesity in the United States, 2009-2010. NCHS Data Brief 2012;82:1-8.

60 Godfrey KM, Gluckman PD, Hanson MA: Developmental origins of metabolic disease: life course and intergenerational perspectives. Trends Endocrinol Metab 2010;21:199-205.

61 Koletzko B: Project Early Nutrition. Munich, Ludwig Maximilians University, 2012. http:// www.project-earlynutrition.eu/index_science.html.

62 Lehnen $\mathrm{H}$, Zechner U, Haaf T: Epigenetics of gestational diabetes mellitus and offspring health: the time for action is in early stages of life. Mol Hum Reprod 2013;19:415-422.

63 Ong KK, Loos RJ: Rapid infancy weight gain and subsequent obesity: systematic reviews and hopeful suggestions. Acta Paediatr 2006; 95:904-908.

64 Ravelli GP, Stein ZA, Susser MW: Obesity in young men after famine exposure in utero and early infancy. N Engl J Med 1976;295: 349-353.

65 Herrera E, Amusquivar E: Lipid metabolism in the fetus and the newborn. Diabetes Metab Res Rev 2000;16:202-210.

66 Catalano PM, McIntyre HD, Cruickshank JK, McCance DR, Dyer AR, Metzger BE, Lowe LP, Trimble ER, Coustan DR, Hadden DR, Persson B, Hod M, Oats JJ: The hyperglycemia and adverse pregnancy outcome study: associations of GDM and obesity with pregnancy outcomes. Diabetes Care 2012;35:780-786.

67 Nehring I, Chmitorz A, Reulen H, von Kries R, Ensenauer R: Gestational diabetes predicts the risk of childhood overweight and abdominal circumference independent of maternal obesity. Diabet Med 2013;30:1449-1456.

68 Poston L: Intergenerational transmission of insulin resistance and type 2 diabetes. Prog Biophys Mol Biol 2011;106:315-322.

69 Rkhzay-Jaf J, O’Dowd JF, Stocker CJ: Maternal obesity and the fetal origins of the metabolic syndrome. Curr Cardiovasc Risk Rep 2012;6:487-495.

70 Pirkola J, Pouta A, Bloigu A, Hartikainen AL, Laitinen J, Jarvelin MR, Vaarasmaki M: Risks of overweight and abdominal obesity at age 16 years associated with prenatal exposures to maternal prepregnancy overweight and gestational diabetes mellitus. Diabetes Care 2010; 33:1115-1121.

71 Rathnayake KM, Satchithananthan A, Mahamithawa S, Jayawardena R: Early life predictors of preschool overweight and obesity: a case-control study in Sri Lanka. BMC Public Health 2013;13:994.

72 Sacco MR, de Castro NP, Euclydes VL, Souza JM, Rondo PH: Birth weight, rapid weight gain in infancy and markers of overweight and obesity in childhood. Eur J Clin Nutr 2013;67:1147-1153.

73 Stettler N, Zemel BS, Kumanyika S, Stallings VA: Infant weight gain and childhood overweight status in a multicenter, cohort study. Pediatrics 2002;109:194-199. 
74 Shapiro LR, Crawford PB, Clark MJ, Pearson DL, Raz J, Huenemann RL: Obesity prognosis: a longitudinal study of children from the age of 6 months to 9 years. Am J Public Health 1984;74:968-972.

75 Eid EE: Follow-up study of physical growth of children who had excessive weight gain in first six months of life. Br Med J 1970;2:74-76.

-76 Stettler N, Bovet P, Shamlaye H, Zemel BS, Stallings VA, Paccaud F: Prevalence and risk factors for overweight and obesity in children from Seychelles, a country in rapid transition: the importance of early growth. Int J Obes Relat Metab Disord 2002;26:214-219.

77 Mellbin T, Vuille JC: Weight gain in infancy and physical development between 7 and 10 1/2 years of age. Br J Prev Soc Med 1976;30: 233-238.

78 Gunnarsdottir I, Thorsdottir I: Relationship between growth and feeding in infancy and body mass index at the age of 6 years. Int J Obes Relat Metab Disord 2003;27:1523-1527.

-79 Kinra S, Baumer JH, Davey Smith G: Early growth and childhood obesity: a historical cohort study. Arch Dis Child 2005;90:11221127.

-80 Reilly JJ, Armstrong J, Dorosty AR, Emmett PM, Ness A, Rogers I, Steer C, Sherriff A, Avon Longitudinal Study of P, Children Study T: Early life risk factors for obesity in childhood: cohort study. BMJ 2005;330:1357.

-81 Cameron N, Pettifor J, De Wet T, Norris S: The relationship of rapid weight gain in infancy to obesity and skeletal maturity in childhood. Obes Res 2003;11:457-460.

-82 Toschke AM, Grote V, Koletzko B, von Kries R: Identifying children at high risk for overweight at school entry by weight gain during the first 2 years. Arch Pediatr Adolesc Med 2004;158:449-452.

83 Ekelund U, Ong KK, Linne Y, Neovius M, Brage S, Dunger DB, Wareham NJ, Rossner S: Association of weight gain in infancy and early childhood with metabolic risk in young adults. J Clin Endocrinol Metab 2007;92: 98-103.

84 Monteiro PO, Victora CG, Barros FC, Monteiro LM: Birth size, early childhood growth, and adolescent obesity in a Brazilian birth cohort. Int J Obes Relat Metab Disord 2003;27:1274-1282.

-85 Stettler N, Stallings VA, Troxel AB, Zhao J, Schinnar R, Nelson SE, Ziegler EE, Strom BL: Weight gain in the first week of life and overweight in adulthood: a cohort study of European American subjects fed infant formula. Circulation 2005;111:1897-1903.

-86 Euser AM, Finken MJ, Keijzer-Veen MG, Hille ET, Wit JM, Dekker FW, Dutch P-CSG: Associations between prenatal and infancy weight gain and BMI, fat mass, and fat distribution in young adulthood: a prospective cohort study in males and females born very preterm. Am J Clin Nutr 2005;81:480-487.
87 Stettler N, Kumanyika SK, Katz SH, Zemel BS, Stallings VA: Rapid weight gain during infancy and obesity in young adulthood in a cohort of African Americans. Am J Clin Nutr 2003;77:1374-1378.

88 Weng SF, Redsell SA, Swift JA, Yang M, Glazebrook CP: Systematic review and meta-analyses of risk factors for childhood overweight identifiable during infancy. Arch Dis Child 2012;97:1019-1026.

89 Baird J, Fisher D, Lucas P, Kleijnen J, Roberts H, Law C: Being big or growing fast: systematic review of size and growth in infancy and later obesity. BMJ 2005;331:929.

-90 Eriksson J, Forsen T, Osmond C, Barker D: Obesity from cradle to grave. Int J Obes Relat Metab Disord 2003;27:722-727.

-91 Dunger DB, Salgin B, Ong KK: Session 7: early nutrition and later health early developmental pathways of obesity and diabetes risk. Proc Nutr Soc 2007;66:451-457.

92 Ekelund U, Ong KK, Linne Y, Neovius M, Brage S, Dunger DB, Wareham NJ, Rossner S: Association of weight gain in infancy and early childhood with metabolic risk in young adults. J Clin Endocrinol Metab 2007;92:98103.

93 Horta BL, Victora CG, Lima RC, Post P: Weight gain in childhood and blood lipids in adolescence. Acta Paediatr 2009;98:10241028.

-94 Koletzko B, von Kries R, Closa R, Escribano J, Scaglioni S, Giovannini M, Beyer J, Demmelmair H, Gruszfeld D, Dobrzanska A, Sengier A, Langhendries JP, Rolland Cachera MF, Grote V: Lower protein in infant formula is associated with lower weight up to age $2 \mathrm{y}$ : a randomized clinical trial. Am J Clin Nutr 2009;89:1836-1845.

$\$ 95$ Pinot de Moira A, Power C, Li L: Changing influences on childhood obesity: a study of 2 generations of the 1958 British birth cohort. Am J Epidemiol 2010;171:1289-1298.

-96 Cnattingius S, Villamor E, Lagerros YT, Wikstrom AK, Granath F: High birth weight and obesity - a vicious circle across generations. Int J Obes (Lond) 2012;36:1320-1324.

-97 Classen TJ: Measures of the intergenerational transmission of body mass index between mothers and their children in the United States, 1981-2004. Econ Hum Biol 2010;8: $30-43$.

-98 Blasbalg TL, Hibbeln JR, Ramsden CE, Majchrzak SF, Rawlings RR: Changes in consumption of omega-3 and omega- 6 fatty acids in the United States during the 20th century. Am J Clin Nutr 2011;93:950-962.

-99 Harris WS, Klurfeld DM: Twentieth-century trends in essential fatty acid intakes and the predicted omega- 3 index: evidence versus estimates. Am J Clin Nutr 2011;93:907-908.

100 Ailhaud G, Massiera F, Weill P, Legrand P, Alessandri JM, Guesnet P: Temporal changes in dietary fats: role of $n-6$ polyunsaturated fatty acids in excessive adipose tissue development and relationship to obesity. Prog Lipid Res 2006;45:203-236.
101 Spalding KL, Arner E, Westermark PO, Bernard S, Buchholz BA, Bergmann O, Blomqvist L, Hoffstedt J, Naslund E, Britton T, Concha H, Hassan M, Ryden M, Frisen J, Arner P: Dynamics of fat cell turnover in humans. Nature 2008;453:783-787.

102 Hauner H, Brunner S, Amann-Gassner U: The role of dietary fatty acids for early human adipose tissue growth. Am J Clin Nutr 2013;98:549S-555S.

103 Azain MJ: Role of fatty acids in adipocyte growth and development. J Anim Sci 2004; 82:916-924.

104 Hutley LJ, Newell FM, Joyner JM, Suchting SJ, Herington AC, Cameron DP, Prins JB: Effects of rosiglitazone and linoleic acid on human preadipocyte differentiation. Eur J Clin Invest 2003;33:574-581.

105 Alvheim AR, Malde MK, Osei-Hyiaman D, Lin YH, Pawlosky RJ, Madsen L, Kristiansen K, Froyland L, Hibbeln JR: Dietary linoleic acid elevates endogenous 2-AG and anandamide and induces obesity. Obesity (Silver Spring) 2012;20:1984-1994.

106 Massiera F, Saint-Marc P, Seydoux J, Murata $T$, Kobayashi T, Narumiya S, Guesnet $P$, Amri EZ, Negrel R, Ailhaud G: Arachidonic acid and prostacyclin signaling promote adipose tissue development: a human health concern? J Lipid Res 2003;44:271-279.

107 Moon RJ, Harvey NC, Robinson SM, Ntani G, Davies JH, Inskip HM, Godfrey KM, Dennison EM, Calder PC, Cooper C: Maternal plasma polyunsaturated fatty acid status in late pregnancy is associated with offspring body composition in childhood. J Clin Endocrinol Metab 2013;98:299-307.

108 Donahue SM, Rifas-Shiman SL, Gold DR, Jouni ZE, Gillman MW, Oken E: Prenatal fatty acid status and child adiposity at age 3 y: results from a US pregnancy cohort. Am J Clin Nutr 2011;93:780-788.

109 Rytter D, Bech BH, Christensen JH, Schmidt EB, Henriksen TB, Olsen SF: Intake of fish oil during pregnancy and adiposity in 19-y-old offspring: follow-up on a randomized controlled trial. Am J Clin Nutr 2011;94:701-708.

110 Hauner H, Much D, Vollhardt C, Brunner S, Schmid D, Sedlmeier EM, Heimberg E, Schuster T, Zimmermann A, Schneider KT, Bader BL, Amann-Gassner U: Effect of reducing the n-6:n-3 long-chain PUFA ratio during pregnancy and lactation on infant adipose tissue growth within the first year of life: an open-label randomized controlled trial. Am J Clin Nutr 2012;95:383-394.

111 Muhlhausler BS, Gibson RA, Makrides M: Effect of long-chain polyunsaturated fatty acid supplementation during pregnancy or lactation on infant and child body composition: a systematic review. Am J Clin Nutr 2010;92:857-863.

112 Rodriguez G, Iglesia I, Bel-Serrat S, Moreno LA: Effect of n-3 long chain polyunsaturated fatty acids during the perinatal period on later body composition. Br J Nutr 2012; 107(suppl 2):S117-S128. 
$113 \mathrm{Hu} \mathrm{T}$, Mills KT, Yao L, Demanelis K, Eloustaz M, Yancy WS Jr, Kelly TN, He J, Bazzano LA: Effects of low-carbohydrate diets versus low-fat diets on metabolic risk factors: a meta-analysis of randomized controlled clinical trials. Am J Epidemiol 2012; 176(suppl 7):S44-S54.

114 Schwingshackl L, Hoffmann G: Comparison of effects of long-term low-fat versus highfat diets on blood lipid levels in overweight or obese patients: a systematic review and meta-analysis. J Acad Nutr Diet 2013;113: $1640-1661$.

115 Sacks FM, Bray GA, Carey VJ, Smith SR, Ryan DH, Anton SD, McManus K, Champagne CM, Bishop LM, Laranjo N, Leboff MS, Rood JC, de Jonge L, Greenway FL, Loria $\mathrm{CM}$, Obarzanek E, Williamson DA: Comparison of weight-loss diets with different compositions of fat, protein, and carbohydrates. N Engl J Med 2009;360:859-873.
16 Alhassan S, Kim S, Bersamin A, King AC, Gardner CD: Dietary adherence and weight loss success among overweight women: results from the A to $\mathrm{Z}$ weight loss study. Int J Obes (Lond) 2008;32:985-991.

117 McLaughlin T, Abbasi F, Lamendola C, Reaven G: Heterogeneity in the prevalence of risk factors for cardiovascular disease and type 2 diabetes mellitus in obese individuals: effect of differences in insulin sensitivity. Arch Intern Med 2007;167:642-648.

118 Cornier MA, Donahoo WT, Pereira R, Gurevich I, Westergren R, Enerback S, Eckel PJ, Goalstone ML, Hill JO, Eckel RH, Draznin B: Insulin sensitivity determines the effectiveness of dietary macronutrient composition on weight loss in obese women. Obes Res 2005; 13:703-709.

-119 Ebbeling CB, Leidig MM, Feldman HA, Lovesky MM, Ludwig DS: Effects of a lowglycemic load vs low-fat diet in obese young adults: a randomized trial. JAMA 2007;297: 2092-2102.
20 McClain AD, Otten JJ, Hekler EB, Gardner $\mathrm{CD}$ : Adherence to a low-fat vs. low-carbohydrate diet differs by insulin resistance status. Diabetes Obes Metab 2013;15:87-90.

121 Luscombe-Marsh ND, Noakes M, Wittert GA, Keogh JB, Foster P, Clifton PM: Carbohydrate-restricted diets high in either monounsaturated fat or protein are equally effective at promoting fat loss and improving blood lipids. Am J Clin Nutr 2005;81:762-772.

122 Kastorini CM, Milionis HJ, Esposito K, Giugliano D, Goudevenos JA, Panagiotakos DB: The effect of Mediterranean diet on metabolic syndrome and its components: a meta-analysis of 50 studies and 534,906 individuals. J Am Coll Cardiol 2011;57:12991313.

123 Adair LS: Child and adolescent obesity: epidemiology and developmental perspectives. Physiol Behav 2008;94:8-16. 